\title{
Mercury in the sea turtle Chelonia mydas (Linnaeus, 1958) from Ceará coast, NE Brazil
}

\author{
MOISÉS F. BEZERRA ${ }^{1}$, LUIZ D. LACERDA ${ }^{1}$, BRENO G.B. COSTA $^{1}$ and EDUARDO H.S.M. LIMA ${ }^{2}$ \\ ${ }^{1}$ Laboratório de Biogeoquímica Costeira, Instituto de Ciências do Mar, Universidade Federal do Ceará, \\ Av. Abolição 3207, 60165-081 Fortaleza, CE, Brasil. \\ ${ }^{2}$ Fundação Centro Brasileiro de Proteção e Pesquisa das Tartarugas Marinhas. Acesso Projeto TAMAR 151, \\ Alto Alegre, 62592-000 Itarema, CE, Brasil.
}

Manuscript received on December 16, 2010; accepted for publication on April 18, 2011

\begin{abstract}
Mercury concentrations in carapace fragments of the green turtle Chelonia mydas from the Ceará coast in NE Brazil are reported. Concentrations varied from $<0.34$ to 856.6 ng.g- ${ }^{-1}$ d.w., and were highest (average of 154.8 ng.g ${ }^{-1}$ d.w.) in juveniles $(n=22)$, whereas lowest concentrations (average of 2.5 ng.g-1 d.w.) were observed in adult/sub-adult animals $(n=3)$. There was a significant negative correlation between animal size and $\mathrm{Hg}$ concentration probably due to different diets between juveniles and sub-adults/adults. Carapace fragments, which are non-invasive, non-lethal substrates, may be of importance for monitoring purposes of these generally endangered species.
\end{abstract}

Key words: Pollution, metals, marine turtles, monitoring.

\section{INTRODUCTION}

Sea turtles are widely spread throughout the world's tropical and temperate oceans. They are long-living animals and forage on diverse marine food chains; therefore, they have been proposed as bio-indicators of anthropogenic impacts on oceanic systems (Kampalath et al. 2006, Day et al. 2005). Also, sea turtles have been the object of many studies on the effects of global scale, persistent contaminants, mostly metals and organic micro-pollutants, which

Correspondence to: Luiz Drude de Lacerda

E-mail:1drude@pq.cnpq.br have been responsible for the decrease in their populations (Storelli and Marcotrigiano 2003, Lam et al. 2004). Such studies have been carried out among sea turtle populations in the Mediterranean (e.g. Storelli and Marcotrigiano 2003, Storelli et al. 2005) in the Pacific Ocean (e.g. Sakai et al. 2000a, b, Lam et al. 2004) and in the North Atlantic Ocean (e.g. Day et al. 2005). In Brazil, concentrations of metal pollutants, including $\mathrm{Hg}$, are scarcely know, and the available results are based on a few individuals and restricted in geographical distribution along the country's coast (Soto et al. 2005, Barbieri 2009). 
Among the most ubiquitous global persistent pollutants, $\mathrm{Hg}$ is frequently found in relatively high concentrations in the open ocean biota due to worldwide atmospheric deposition, in particular in the northern hemisphere due to elevated anthropogenic emissions and its property of biomagnification through long food chains. Therefore, $\mathrm{Hg}$ is considered a key pollutant to which sea turtles are exposed (Kampalath et al. 2006, Day et al. 2005).

The coast of Ceará in NE Brazil is a known feeding, growing and migration corridor of 5 species of sea turtles. The green turtle, Chelonia mydas (Linnaeus, 1958), is the most frequent and abundant species that occurs in this littoral. The species is considered threatened of extinction in Brazil and at a global level (Lima 2001). Chelonia mydas is an omnivorous species. When juveniles, however, C. mydas mostly preys on small benthic and pelagic invertebrates, whereas as adults/sub-adults this turtle becomes almost strictly herbivorous, feeding on algae and sea grasses (Cardona et al. 2010).

The major pathway of $\mathrm{Hg}$ exposure and accumulation in long-living marine animals including birds, mammals and sea turtles is their diet (Kehrig et al. 2009), but little is known on the uptake, bioaccumulation and bioconcentration mechanisms that result in a given body or organ concentration mainly due to the difficulty in sampling and handling these animals under strict protocols based on wildlife protection standards. Most studies are based on results from dead or dying animals generally in small numbers (Storelli et al. 2005, Storelli and Marcotrigiano 2003, Lam et al. 2004). Therefore, any additional, reliable data on pollutant concentrations in these organisms are important to sum up a workable database to help the understanding of pollutant fate in this oceanic biota.

The major objective of this study is to provide additional $\mathrm{Hg}$ concentration data on the green turtle C. mydas from a region where no information is available. Also, it aims at testing the response of $\mathrm{Hg}$ concentration in carapace fragments, which are non-invasive, non-destructive substrates, to animal size and diet, and finding out on their utility to improve future monitoring programs, respecting wildlife protection protocols, on $\mathrm{Hg}$ distribution in the marine biota.

\section{MATERIALS AND METHODS}

All samples collected for this study followed the accepted protocols for wildlife handling and sampling according to SISBIO License No. 21693-1 from October 2009. Ceará coastline extends through $573 \mathrm{~km}$ in the semi-arid region of NE Brazil. This western portion of this coast is an important feeding site and migration route of 5 from the 7 known species of sea turtles, which resulted in the establishment of a protection and conservation unit of the Brazilian Program on Sea Turtle Conservation (TAMAR/ ICMBio) from the Ministry of the Environment. The unit is located in Almofala Beach, Itarema Municipality $\left(02^{\circ} 56^{\prime} 18^{\prime \prime} \mathrm{S}\right.$; 039 $\left.48^{\prime} 51^{\prime \prime} \mathrm{W}\right)$ (Figure 1), where traditional fisheries use mainly fish weirs that frequently capture sea turtles (Lima 2001).

The sampling included 20 living individuals accidentally trapped in fish weirs and captured by the local TAMAR/ICMBio staff and 5 individuals that were found dead on the beach. The trapped turtles were immediately set free after the biometric data collection. The sampled animals varied in size from 27.4 to 103.1 $\mathrm{cm}$ (average $50.5 \pm 17.0 \mathrm{~cm}$ ) and weighted from 1.7 to $45.0 \mathrm{~kg}$ (average $11.4 \pm 8.6 \mathrm{~kg}$ ). The animals could be divided in roughly two groups based on size, one represented by 22 juvenil individuals with CCL varying from 36.4 and $55.3 \mathrm{~cm}$ and a second group of 3 sub-adult/adult individuals with CCL varying from 85.0 and $103.1 \mathrm{~cm}$. Keratinized carapace fragments were collected from both groups. Only those fragments presenting signs of loss were collected in living animals, e.g. due to barnacle incrustation. Fragments were labeled and preserved frozen in plastic bags until analysis. Species identification and biometry, weight, curved carapace length (CCL) and carapace width $(\mathrm{CW})$, were obtained during sampling. 


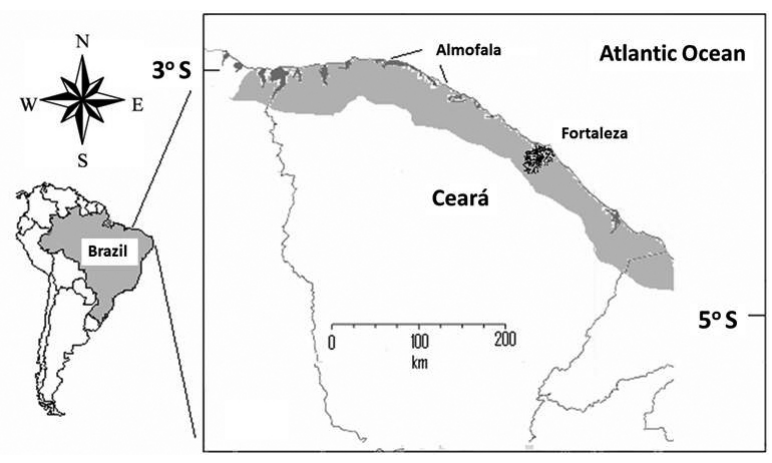

Figure 1. Map showing the location of Almofala coast in Ceará State, Brazil, where samples were obtained.

In the laboratory keratin fragment samples were treated in an ultra-sonic bath to fully remove algae and other incrusting residues and sediment grains. Duplicate sub-samples of each individual weighting about 0.5 g were transferred to Teflon ${ }^{\circledR}$ tubes containing $10 \mathrm{~mL}$ of concentrated $\mathrm{HNO}_{3}$ and left there for 1 hour. The tubes were then transferred to a microwave oven (MARS XPRESS - CEM), $400 \mathrm{~W}$ at $200^{\circ} \mathrm{C}$ for 30 min. After cooling, $1 \mathrm{~mL}$ of $\mathrm{H}_{2} \mathrm{O}_{2}$ was added and the solution diluted to $100 \mathrm{~mL}$ with ultra-pure $(<3 \mu \mathrm{S})$ water. Mercury concentrations were quantified through cold vapor atomic absorption spectrophotometry (CV-AAS) in a Nippon Instrumentation Corporation (NIC RA ${ }^{-3}$ ) spectrophotometer. Simultaneously, Hg concentrations were measured in duplicate in two reference standards, and the recovery of referenced values varied from 105\% for BCR 060 (aquatic plant tissue) with nominal $\mathrm{Hg}$ concentration of $340 \mathrm{ng} \cdot \mathrm{g}^{-1}$ to $106 \%$ for NIST 2976 (mussel tissue) with nominal $\mathrm{Hg}$ concentration of $64 \mathrm{ng} \cdot \mathrm{g}^{-1}$. The detection limit of the procedure was $0.59 \mathrm{ng}\left(0.34 \mathrm{ng} . \mathrm{g}^{-1}\right)$ considering three times the standard deviation of reagent blanks (EPADYX) divided by the inclination of the calibration curve $(2.5-20 \mathrm{ng})$.

\section{RESULTS AND DISCUSSION}

Mercury concentrations in carapace fragments among all sampled individuals varied from $<0.34$ to 856.6 ng.g ${ }^{-1}$ d.w. The highest Hg concentrations, with an average of 154.8 ng.g ${ }^{-1}$ d.w., were observed in the juvenile group, whereas the lowest concentrations, with an average of $2.5 \mathrm{ng} . \mathrm{g}^{-1}$ d.w., were observed in sub-adult/adult animals. There was a significant negative correlation $(\mathrm{P}<0.01 ; \mathrm{n}=25)$ between animal size (CCL) and $\mathrm{Hg}$ concentration (Figure 2) when the entire range of size is included, but no significant correlation was found between $\mathrm{Hg}$ concentrations and weight, which was expected since individuals may be under different foraging state and degree of stress due to capture, which would affect their body weight. Even when only juveniles are plotted, the negative correlation between $\mathrm{Hg}$ concentrations and animal size can still be identified (Figure 3 ).

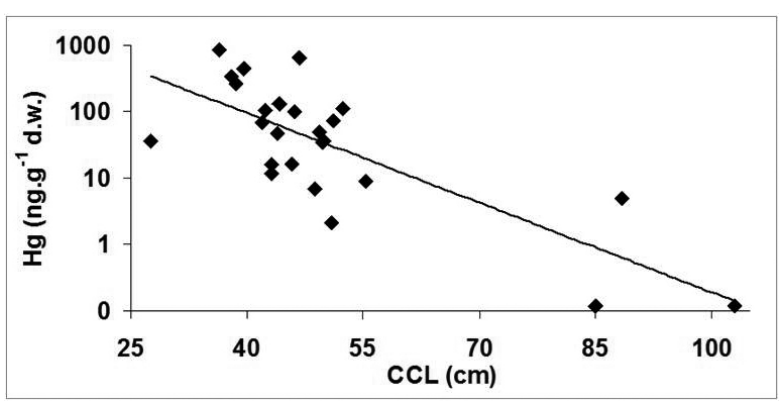

Figure 2. Significant negative correlation $(\mathrm{n}=25 ; \mathrm{p}<0.01)$ between total $\mathrm{Hg}$ concentrations and curved carapace length (CCL) observed in the sea turtle C. mydas from the Ceará coast in NE Brazil.

Sexual maturation in $C$. mydas starts when individuals reach about $1 \mathrm{~m}$ in CCL (Heppell et al. 2003), and individuals smaller than $35 \mathrm{~cm}$ in straight carapace length (SCL) (corresponding to 40 to $50 \mathrm{~cm}$ in CCL) (Zug et al. 2002) and with about $6 \mathrm{~kg}$ are considered immature juveniles. The major group of animals analyzed in this study thus fell in this category. After hatching, juvenile C. mydas enter 3 to 5 years of oceanic stage and forage on invertebrates from the neuston, as well as small benthic animals (Senko et al. 2010). When they recruit to inshore foraging habitats their diet shifts from the omnivorous planktivory of a pelagic turtle to the herbivorous diet of an inshore immature turtle finally foraging exclusively on benthic algae and 
sea grasses when reaching sexual maturity (Arthur and Balazs 2008, Bolten 2003, Cardona et al. 2010). This changing of the major diet items and the large range in size explain, in part, the high variability of $\mathrm{Hg}$ concentrations observed among individuals. Juvenile individuals showed a significant negative correlation between size and $\mathrm{Hg}$ concentrations, which is in accordance with a progressive acquiring of herbivory and can be interpreted as a response to higher organic $\mathrm{Hg}$ contents in the neuston and benthic animals, preyed by juveniles, relative to benthic plants, preyed by mature turtles. This may explain the higher concentrations found in the smaller animals, which should have just been recruited to the inshore foraging habitat. Also the preference of juveniles for coastal habitats can result in a higher exposure to $\mathrm{Hg}$ that is relatively abundant in these environments, as shown for the Ceará coast (Lacerda et al. 2007). Kampalath et al. (2006) also observed negative correlations between animal size and $\mathrm{Hg}$ content, but in the internal organs of C. mydas. These authors also associated this pattern with a change in diet between smaller and larger animals. It is important to consider that the pattern verified for the carapace fragments in this study is the same found for internal organs by these authors.

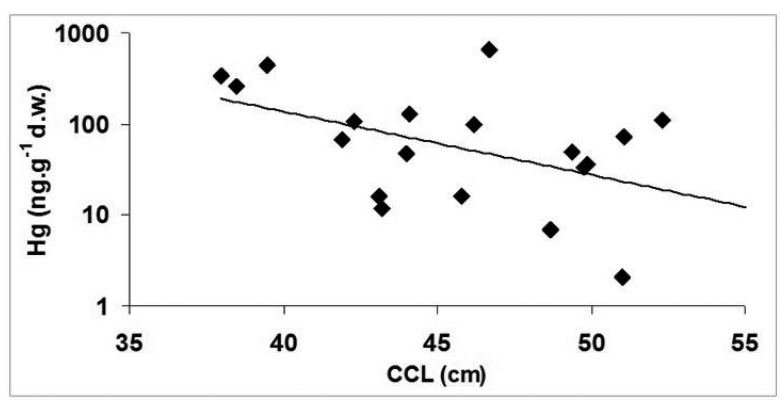

Figure 3. Significant negative correlation $(n=19 ; \mathrm{p}<0.05)$ between total $\mathrm{Hg}$ concentrations and curved carapace length (CCL) of living juvenile individuals of C. mydas from the Ceará coast in NE Brazil.

Few studies using the carapace fragments of C. mydas as an experimental subject have been published, making difficult the comparison of our results. Sakai et al. (2000a, b) found $\mathrm{Hg}$ concentrations varying from 2.09 to $2.79{\mathrm{ng} . \mathrm{g}^{-1}}^{-1}$ in two adult individuals. These concentrations are in agreement with those found in the three adult individuals from the Ceará coast. They also found a good correlation between the $\mathrm{Hg}$ content in these carapaces and $\mathrm{Hg}$ concentrations in the whole body, confirming the possible use of carapace fragments as a desirable non-invasive sample for monitoring purposes. Lam et al. (2004) reported Hg concentrations in C. mydas varying from $200 \mathrm{ng} . \mathrm{g}^{-1}$ in lungs to $780 \mathrm{ng}^{-\mathrm{g}^{-1}}$ in the liver of two juvenile individuals. In the same study they reported $\mathrm{Hg}$ concentrations in the muscles and liver of 3 adult individuals of $53 \mathrm{ng} \cdot \mathrm{g}^{-1}$ and $124 \mathrm{ng} . \mathrm{g}^{-1}$, respectively. Although the carapace was not analyzed by these authors, our average results, even for juveniles, are in the lower range of reported $\mathrm{Hg}$ concentrations for this species, which suggests a smaller $\mathrm{Hg}$ exposure.

The most available results are from other turtle species, which unfortunately hampers direct comparisons with our results, but may provide an overview of the $\mathrm{Hg}$ distribution in this group of animals. Day et al. (2005), for example, found comparable results, both regarding the concentration range and distribution among individuals of different size for Caretta caretta. A. Green, unpublished data observed a significant correlation between the $\mathrm{Hg}$ concentrations in the carapace with those present in other internal organs in freshwater turtle species from Asia. This author also found a significant negative correlation between $\mathrm{Hg}$ content and size of individuals, which is also associated with different diets. Unfortunately all these results are based on less than 10 animals, thus still avoiding the discussion of a general pattern of $\mathrm{Hg}$ fate in sea turtles. In Brazil, only two studies, to our knowledge, have quantified metal concentrations in sea turtles, and only one dealt with $\mathrm{Hg}$ (Soto et al. 2005). All of them have analyzed internal organs (Barbieri 2009). In another study, Schneider et al. (2009) published the only account of $\mathrm{Hg}$ concentrations in carapace fragments, of the freshwater turtle Podocnemis erythrocephala from 
the Amazon region and found strong correlations between $\mathrm{Hg}$ and size of the individuals, but no significant correlations between $\mathrm{Hg}$ concentration in internal organs and size.

The $\mathrm{Hg}$ concentrations observed in the carapace fragments of the larger (adult/sub-adult) animals sampled in the present study are very low as a response to their herbivorous diet. However, those found in juveniles are much higher, which is also a response to the preferentially carnivorous diet. The concentrations are in general lower than the $\mathrm{Hg}$ content found in top marine carnivorous animals such as mammals and sea birds (Bond and Antony 2009, Kehrig et al. 2009).

\section{CONCLUSION}

The results presented in this study are the first ever published on the $\mathrm{Hg}$ concentrations in C. mydas in northeastern Brazil using keratinized carapace fragments. Concentrations are in the lower range of those observed in the carapaces of other species of sea turtles, and much lower than those observed in internal organs. On the other hand, carapace fragments proved to be a reliable, available and non-invasive, non-lethal subject for the $\mathrm{Hg}$ monitoring. Much more research, however, is needed to associate carapace concentrations with $\mathrm{Hg}$ body burden and environmental $\mathrm{Hg}$ levels, since carapace fragments could be the basis for a future monitoring program on the $\mathrm{Hg}$ contamination of pelagic environments along the Brazilian coast. Thus, it would avoid unnecessary deaths of animals and allow the work with living animals actually exposed to present $\mathrm{Hg}$ concentrations in the oceans.

\section{ACKNOWLEDGMENTS}

We are deeply indebted to Projeto TAMAR/ICMBio Regional Ceará for logistic support and sample collection. The Instituto Nacional de Ciência e Tecnologia de Transferência de Material Continente-
Oceano (INCT-TMCOcean), Conselho Nacional de Desenvolvimento Científico e Tecnológico (CNPq Proc. No. 573.601/2008-9) funded this research.

\section{RESUMO}

As concentrações de $\mathrm{Hg}$ em fragmentos de carapaça de Chelonia mydas no litoral do Ceará, nordeste do Brasil, são reportadas. Concentrações variaram de $<0,34$ a 856,6 ng. $\mathrm{g}^{-1}$ em peso seco, e foram maiores (média de 154,8 ng.g $\mathrm{g}^{-1}$ em peso seco) em indivíduos juvenis $(n=22)$, enquanto que as menores concentrações (média de 2,5 ng.g ${ }^{-1}$ em peso seco) foram observadas em indivíduos adultos/sub-adultos $(\mathrm{n}=3)$. Houve uma correlação negativa significativa entre tamanho do animal e concentração de $\mathrm{Hg}$ provavelmente devido a diferença de dieta entre juvenis e sub-adultos/adultos. Fragmentos de carapaça, que constituem substratos não-invasivos e não letais, podem ser importantes para fins de monitoramento ambiental dessas espécies ameaçadas de extinção.

Palavras-chave: Poluição, metais, tartarugas marinhas, monitoramento.

\section{REFERENCES}

ARTHUR KE AND BALAZS GH. 2008. Comparison of immature green turtle (Chelonia mydas) diets among seven sites in the main Hawaiian Islands. Pacific Sci 62: 205-217.

BARBIERI E. 2009. Concentration of heavy metals in tissues of green turtles (Chelonia mydas) sampled in the Cananéia estuary, Brazil. Braz J Oceanogr 57: 243-248.

Bolten AB. 2003. Variation in sea turtle life history patterns: Neritic vs. oceanic development stages. In: Lutz PL, Musick JA and Wyneken J (Eds), THE BIOLOGY OF SEA TURTLES. CRC Press, Washington, DC 2: 243-257.

BOND AL AND ANTONY WD. 2009. Total and methyl mercury concentrations in seabird feathers and eggs. Environ Contam Toxicol 56: 286-291.

Cardona L, Campos P, LeVy Y, Demetropoulos A AND MARGARITOULIS D. 2010. Asynchrony between dietary and nutritional shifts during the ontogeny of green turtles (Chelonia mydas) in the Mediterranean. J Exper Mar Biol. Ecol 393: 83-89. 
DAY RD, CHRISTOPHER SJ, BECKER PR AND WHITAKER DW. 2005. Monitoring mercury in the loggerhead sea turtle, Caretta caretta. Environ Sci Technol 39: 437-446.

Heppell SS, SNOver ML AND Crowder LB. 2003. Sea turtle population ecology. In: Lutz PL, Musick JA and Wyneken J (Eds), THE BIOLOGY OF SEA TURTLES. CRC Press, Washington, DC 2: 275-299.

KAMPALATH R, GARDNER SC, MÉNDEZ-RodríGUEZ L AND JAY JA. 2006. Total and methylmercury in three species of sea turtles of Baja California Sur. Mar Pollut Bull 52: 1784-1832.

KeHrig HA, FERnANDES KWG AND MaLm O. 2009. Transferência trófica de mercúrio e selênio na costa norte do Rio de Janeiro. Quim Nov 32: 1822-1828.

LACERDA LD, SANTOS JA, CAMpos RC, GonçAlves RA AND SAlles R. 2007. Total-Hg and organic-Hg in Cephalopholis fulva (Linnaeus, 1758) from inshore and offshore waters of NE Brazil. Braz J Biol 67: 493-498.

LAM JCW, TANABE S, Chan SAKF, YUEN EKW, LAM MHW AND LAM PKS. 2004. Trace element residues in tissues of green turtles (Chelonia mydas) from South China Waters. Mar Pollut Bull 48: 164-192.

LIMA EHSM. 2001. Helping the people help the turtles: The work of Projeto TAMAR-IBAMA in Almofala, Brazil. Mar Turtles Newslet 91: 7-9.

Sakai H, Saeki K, Hichihashi H, Kamizaki N, TANabe S AND TATSUKAWA R. 2000a. Growth-related changes in heavy metal accumulation in green turtle (Chelonia mydas) from Yaeyama Islands, Okinawa, Japan. Archiv Environ Contam Toxicol 39: 378-385.
Sakai H, Saeki K, Hichihashi H, Suganuma H, Tanabe S AND TATSUKAWA R. 2000b. Species-specific distribution of heavy metals in tissues and organs of loggerhead turtle (Caretta caretta) and green turtle (Chelonia mydas) from Japanese coastal waters. Mar Pollut Bull 40: 701-709.

Schneider L, Belger L, Burger J AND Vogt RC. 2009. Mercury bioaccumulation in four tissues of Podocnemis erythrocephala (Podocnemididae: Testudines) as a function of water parameters. Sci Tot Environ 407: 1048-1054.

Senko J, López-Castro MC, Koch V AND Nichols WF. 2010. Immature East Pacific green turtle (Chelonia mydas) use multiple foraging areas off the Pacific Coast of Baja California Sur, Mexico: First evidence from markrecapture data. Pacific Sci 64: 125-130.

Soto JMR, SOARES JT, CELINI AAOS AND SANTOS RCA. 2005. Concentração de mercúrio total em tecidos de Caretta caretta (Linnaeus, 1758) (Reptilia, Cheloniidae) encalhadas na costa sul do Rio Grande do Sul, Brasil. In: $2^{\mathrm{a}}$ Jornada de Conservação e Pesquisa de Tartarugas Marinhas no Atlântico Sul Ocidental, Rio Grande, p. 25-27.

StOrelli MM AND Marcotrigiano GO. 2003. Heavy metal residues in tissues of marine turtles. Mar Pollut Bull 46: 397-400.

Storelli MM, Storelli A, D'AdDABbo R, MARANo C, BRUNO R AND MARCOTRIGIANO GO. 2005. Trace elements in loggerhead turtles (Caretta caretta) from the eastern Mediterranean Sea: overview and evaluation. Environ Pollut 135: 163-170.

Zug GR, Balazs GH, Wetherall JA, Parker DM and MURAKAWA SKK. 2002. Age and growth of Hawaiian greee turtle (Chelonia mydas): An analysis based on skeletochronology. Fish Bull 100: 117-127. 